University of Wollongong

Research Online

Faculty of Business - Papers (Archive)

Faculty of Business and Law

$1-1-2015$

Developing CSR giving as a dynamic capability for salient stakeholder management

John Cantrell

University of Wollongong, cantrell@uow.edu.au

Elias Kyriazis

University of Wollongong, kelias@uow.edu.au

Gary Noble

University of Wollongong, gnoble@uow.edu.au

Follow this and additional works at: https://ro.uow.edu.au/buspapers

Part of the Business Commons

Research Online is the open access institutional repository for the University of Wollongong. For further information contact the UOW Library: research-pubs@uow.edu.au 


\title{
Developing CSR giving as a dynamic capability for salient stakeholder management
}

\begin{abstract}
In this paper, we draw upon the emerging view of strategic cognition and issue salience and show that CSR giving has evolved into more than an altruistic response to being asked for support, to one which is embedded in the strategic frames of management and which supports organizational identity. The managerial action as a result of such strategic cognition suggests that modern organizations are seeking to develop CSR giving processes that provide them with a competitive advantage. We draw on the resource-based view of organizations and the VRIO framework to provide the theoretical foundations for our argument that CSR implementation in the form of corporate giving to charities can be developed as a dynamic capability. This can provide a competitive advantage by allowing organizations to manage key stakeholder relationships (external and internal) more effectively with benefits which could lead to increased organizational productivity and the ability to execute strategy more effectively. We interview CSR implementation managers from large organizations in Australia and find that the CSR giving process in many firms is evolving into a more sophisticated and strategically motivated process with expectations of a return. Central to this evolution is the appointment of a CSR implementation manager who acts as a boundary spanner between the organization and its key stakeholders. We posit that this corporate investment in their role and supporting structures can lead to the better management of stakeholders by organizations through the dynamic capability of the CSR giving process. We develop a table of best practise to help guide managers entering this sphere.
\end{abstract}

\section{Keywords}

management, stakeholder, salient, csr, capability, developing, dynamic, giving

\section{Disciplines}

Business

\section{Publication Details}

Cantrell, J. Ehsman., Kyriazis, E. \& Noble, G. (2015). Developing CSR giving as a dynamic capability for salient stakeholder management. Journal of Business Ethics, 130 (2), 403-421. 


\title{
Developing CSR Giving as a Dynamic Capability for Salient Stakeholder Management
}

\author{
John Ehsman Cantrell · Elias Kyriazis · Gary Noble \\ Received: 4 November 2013/ Accepted: 14 May 2014
}

\begin{abstract}
In this paper, we draw upon the emerging view of strategic cognition and issue salience and show that CSR giving has evolved into more than an altruistic response to being asked for support, to one which is embedded in the strategic frames of management and which supports organizational identity. The managerial action as a result of such strategic cognition suggests that modern organizations are seeking to develop CSR giving processes that provide them with a competitive advantage. We draw on the resourcebased view of organizations and the VRIO framework to provide the theoretical foundations for our argument that CSR implementation in the form of corporate giving to charities can be developed as a dynamic capability. This can provide a competitive advantage by allowing organizations to manage key stakeholder relationships (external and internal) more effectively with benefits which could lead to increased organizational productivity and the ability to execute strategy more effectively. We interview CSR implementation managers from large organizations in Australia and find that the CSR giving process in many firms is evolving into a more sophisticated and strategically motivated process with expectations of a return. Central to this evolution is the appointment of a CSR implementation manager who acts as a boundary spanner between the organization and its key stakeholders. We posit that this corporate investment in their role and supporting structures can lead to the better management of stakeholders by
\end{abstract}

J. E. Cantrell (\&) · E. Kyriazis · G. Noble

University of Wollongong, Wollongong, NSW, Australia

e-mail: cantrell@uow.edu.au

E. Kyriazis

e-mail: elias_kyriazis@uow.edu.au

G. Noble

e-mail: gary_noble@uow.edu.au organizations through the dynamic capability of the CSR giving process. We develop a table of best practise to help guide managers entering this sphere.

Keywords Corporate philanthropy · CSR · CSR giving · Dynamic capability · Giving manager · Issue salience · RBV · Stakeholders · Stakeholder management · VRIO

\section{Introduction}

Current research suggests that companies are increasingly seeing themselves as social enterprises (c.f. Birch and Littlewood 2004; Thorne et al. 2011) and their stakeholders are increasingly calling on them to create behaviours in business that are seen as socially responsible (Smith 2009; Carroll and Shabana 2010; Thorne et al. 2011). This growing stakeholder influence on the organizations behaviour and in particular how it manifests itself in the organizations CSR policy is "an inescapable reality for business leaders in every country" (Porter and Kramer 2006, p. 1).

The increasing pressure from stakeholders (both internal and external) for social responsibility has meant many corporate giving programs have been subsumed into, are reported as, and included in modern research on organizational CSR, as corporations need to be seen to be socially responsible (c.f. Navarro 1988; Sharfman 1994; Burke and Logsdon 1996; Campbell et al. 2002; Brammer and Millington 2004; Morimoto et al. 2005; and Chen et al. 2008). CSR and corporate support for charities has also been shown to provide differential advantage (Kanter 1999) and competitive advantage (Porter and Kramer 2002) and Vanhamme and Grobben (2009, p. 280) suggested that 'because of the advantages companies can gain from CSR 
involvement, they largely have embraced CSR initiatives through donations or community programs'. Sen et al. (2006, p. 164) state corporate-level intangible assets such as their identities and reputations and the goodwill associated with being a good corporate citizen can be used to garner sustainable competitive advantages, as 'it can be marketed not just to its customers but to other stakeholders (e.g. employees, investors) as well'.

Corporate giving programs are provided as evidence of social responsibility, and a meta-analysis of how CSR activities have been represented in corporate reporting literature (Peloza and Shang 2011) demonstrates how what would once have been termed corporate philanthropy is now presented as CSR. Activities that supported charities reported as CSR include community involvement, environmental protection, diversity and cash donation (Peloza and Shang 2011). Barnett (2007, p. 281) also states that CSR expenditure is "a discretionary allocation of corporate resources toward improving social welfare that serves as a means of enhancing relationships with key stakeholders".

The management of these giving programs and their being subsumed into the wider CSR policies of the firm have led to what was previously called a 'giving manager' (Saiia et al. 2003) becoming in effect a CSR implementation manager, taking on a broader boundary spanning role with greater interaction with key stakeholders. This paper contends that the development of the role of the CSR implementation manager can give life to the various frameworks for implementing CSR (c.f. Maignan et al. 2005; O’Riordan and Fairbrass 2008; Maon et al. 2008, 2009, 2010). In the literature to date little is known about the role of the giving manager or the critical role of the CSR implementation manager and 'CSR design and implementation processes remain largely unexplored' (Maon et al. 2009, p. 71). This managerial role can be seen as a significant nexus in the 'stakeholder dialogue loop' conceptualized by Maon et al. (2008, p. 418); that is the relationships between a corporation and its various stakeholders, particularly those considered as salient.

The CSR implementation manager has to make CSR giving decision or recommendations based on their understanding of the organizations CSR intent and stakeholder issue salience. What has been missing from the literature is an overarching theoretical perspective which enables these managers (and their superiors) to better understand the firms CSR giving decisions from a stakeholder management and issue salience perspective. Hillman and Keim (2001) showed from their research that building better relations with stakeholders could lead to 'firms developing intangible but valuable assets which can be resources of competitive advantage' (p. 126). Murphy et al. (2005) suggest that managing stakeholders and taking their preferences into account in corporate social responsibility policy, action and reporting significantly improves business performance compared to merely focusing on the more traditional customer relationships. Helmig et al. (2013) suggest that there are few studies that have investigated the effect of stakeholder pressure on CSR implementation. They define stakeholder pressure as 'the ability and capacity of stakeholders to affect an organization by influencing its organizational decisions' (p. 4). CSR giving is a classic example of organizations decisions being affected by stakeholder pressure.

This paper proceeds as follows. In the next section we discuss who and what matters for the organization in relation to CSR giving, that is, saliency of both stakeholders and issues. This introduces stakeholder theory and the Strategic Cognition Framework for Issue Salience developed by Bundy et al. (2013). We then discuss why CSR giving matters for the organization, introducing the RBV perspective and discussing how this lens can inform the study of CSR giving within the organization. The following section demonstrates how CSR giving can be considered to be a potential dynamic capability using the VRIO framework to understand the development of this capability. The methodology used in this study is then briefly described, followed by the presentation and discussion of the results of this research framed in the same order as the introduction of the theoretical basis for this paper, the who, what and why of CSR giving and the potential development of a corporate dynamic capability. The paper concludes with a summary of the managerial implications of this research, the limitations of the research, and proposes topics for future research.

\section{Stakeholders, Strategic Cognition and Issue Salience: Who and What Matters to the Corporation}

\section{Stakeholder Theory}

Stakeholder theory is a crucial component for understanding business and societal relationships (c.f. Carroll and Buchholtz 2000; Maon et al. 2010). It is the most commonly used theoretical framework for evaluating CSR (McWilliams and Siegel 2001), and has been discussed in that context for many years. In research by Middlemiss (2003) on the measurement of CSR involving 170 corporate executives and professional communicators across eight countries, "stakeholder surveys" received the most responses for a 'very relevant' method of measuring CSR (the highest measure) and the lowest number of responses for 'not relevant' (the lowest measure). The role of the CSR implementation manager has been confirmed by this research as being predominately involved with the stakeholders of the firm (c.f. also Saiia et al. 2003; 
Cantrell et al. 2008; Maas and Liket 2011). A large amount of this aspect of their role is about issue and stakeholder management and this is central to the discussion in our paper.

Stakeholders of an organization have generally been categorised into primary or secondary stakeholder groups, where according to Freeman (1984) a primary stakeholder group includes customers, competition, employees, investors, shareholders, suppliers and secondary stakeholders are considered to include governments, interest groups and media. Carroll (1993) initially suggested limits be placed on those groups or individuals to be classified as stakeholders, suggesting a stakeholder is only legitimate if they bear some financial or human risk in the relationship, but Carroll and Buchholtz (2000) subsequently adopted a new definition similar to Freeman's broader definitions. Others take a different approach (McManus 2002) by suggesting there are two higher level broad categories-strategic and moral, with strategic stakeholders being those who can affect the organization, and moral stakeholders being those who are affected by the organization. Instead of Carroll's initial 'risk bearing', McManus suggests stakeholders 'compete for ... resources' (2002, p. 9), and proposes producing a stakeholder map, or conducting a series of interviews highlighting contrasting variation between stakeholders in order to identify important strategic and moral stakeholder groups.

Neville et al. (2011, p. 357) believe that 'stakeholder salience holds considerable unrealized potential for understanding how organizations may best manage multiple stakeholder relationships'. Stakeholder salience has been defined as "the degree to which managers give priority to competing stakeholder claims" (Mitchell et al. 1997, p. 854) and Neville et al. (2011, p. 369) argue that the traditional stakeholder salience framework be revised such that power, moral (their inclusion) legitimacy and urgency 'are evaluated on a continuum of degrees and not as dichotomous variables'. Their term "moral" incorporates personal, organizational and socially constructed influences on the manager and they suggest legitimacy be determined with a 'moral' perspective. They believe that better understanding saliency can assist in deciding how to best allocate resources.

Greenley et al. (2004) demonstrated that the perceived variation in the relative importance to the business of each of the stakeholders is associated with differing corporate strategic planning emphasis, and that considering multiple stakeholders results in the prioritization of the various primary stakeholder interests and the allocation of managerial attention and resources to serve them. In this, they are effectively confirming Donaldson and Preston's (1995) extension of stakeholder theory as describing a political model of the firm. Freeman (1999) also supports a political view and notes that in his opinion 'the very idea of a purely descriptive, value free, or value-neutral stakeholder theory is a contradiction in terms' (p. 234). The allocation of managerial attention and resources to satisfy stakeholders with respect to corporate CSR activities is evidenced in large organizations through the creation of the position of the CSR implementation manager. Brammer et al. (2009) suggest their research shows firms are likely to engage in corporate giving to offset the concerns of stakeholders. We agree with this position that a broader view of CSR and corporate giving is required to better inform the results of this research.

From the perspective of CSR giving, stakeholder theory aids in the understanding of the influences and influencers on the organization, and conversely in assisting to understand how the actions of the organization can affect different stakeholders. Large firms understand the relevance of identifying their relationships with stakeholders and their 'emerging strategic orientation toward responsible behaviours justifies the argument that stakeholder theory is sufficient to identify stakeholders that are part of the valuecreating process of the large firm' (Russo and Perrini 2010, pp. 217-218). Russo and Perinni (2010, p. 218) also suggest that what is crucial to a sustainable strategy is the relationship with those stakeholders and the way it is managed'.

Stakeholder theory helps understand and describe 'who' is important to the organization. The CSR implementation manager can both assist the corporation in meeting its legislated goal of shareholder management, as well as playing a major role in the corporation satisfying (or managing) the often conflicting demands of other stakeholders, which is the ideal outcome of 'strategic philanthropy' (McAlister and Ferrell 2002). Thus, stakeholder theory offers a lens to better understand just who the stakeholders are, what responsibilities the organization has to these stakeholders, the relative 'power, legitimacy and urgency' of the various stakeholders (and what opportunities (and/or threats) this presents to the organization.

\section{Strategic Cognition and Issues Salience}

A recent development in theoretical thinking on a strategic approach to stakeholders and stakeholder issue management has been the concept of strategic cognition and issue salience-what is important to the organization. This salience perspective is a managerial framework for understanding, prioritizing and responding to key stakeholder concerns developed by Bundy et al. (2013). The philosophy behind this development is that 'issue salience (is) a key antecedent of firm responsiveness to stakeholder concerns' and that 'it is an intermediating construct' 
(Bundy et al. 2013, p. 369). The framework uses the concepts of desired organizational identity (how the firm wishes to be perceived) and a firm's strategic outlook (how the firm incorporates their desired identity into strategy). Using this framework, managers can therefore understand whether any stakeholder issue can be more or less impactful on the combination of the organizational identity and corporate strategy. The more likely an issue is to support the identity the organization wishes to project, that is 'material to a firm's core values and beliefs' (Bundy et al. 2013, p. 357) the more likely it is to be accepted and supported by the managers of the firm. Conversely, the more the issue is incongruent or conflicting with the organization identity and supported by salient stakeholders, the more likely it is that the firm will respond to it. Similarly, an issue that is interpreted by the manager as being instrumentally salient to the organizations strategic frame, especially if it is supported by a salient stakeholders, is more likely to be noticed and supported; while an issue which seen to be in conflict with desired strategy will be seen as salient, and therefore, receive more attention, and action than those issues perceived to unrelated to the firms strategic frame. The framework presented by Bundy et al. (2013) is reproduced below as it is of significance later in this paper when discussing the CSR implementation manager and the decisions they make. Frameworks such a this allow managers a visual representation of their strategic thought processes and are useful in decision making, we show how this framework has relevance for CSR giving later in the paper (Fig. 1).

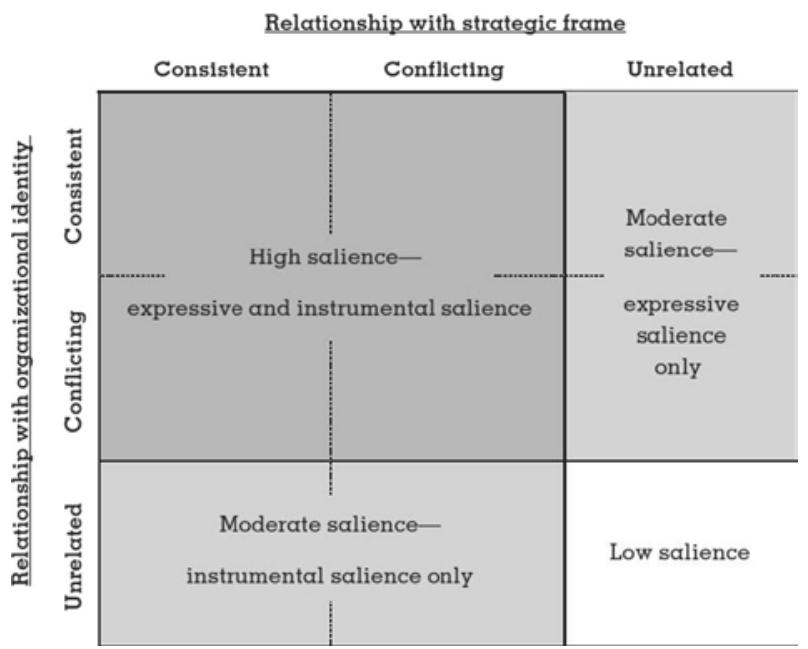

Fig. 1 A strategic cognition framework for issue salience (Bundy et al. 2013, p. 355)
RBV: Why CSR Giving Matters to the Organization

In this paper, we have taken a resource-based view (RBV) of the firm as the most appropriate way to capture the constructs of interest in this study. The dependent variable of interest in our study is a process, the CSR giving process implemented by the firm. The basis of this approach is seminal work by Ray et al. (2004) who argue that there is 'an alternative class of dependent variable - the effectiveness of business processes ...... as a way to test resource based logic' (p. 24). Further, they state:

A final reason to adopt the effectiveness of business processes as a dependent variable in resource-based research is that business processes are the way that the competitive potential of a firm's resources and capabilities are realized and deserve study in their own right. Most scholars acknowledge that resources, by themselves, cannot be a competitive advantage. That is resources can only be a source of competitive advantage if they are used to "do something' that is, if those resources are exploited through business processes.

We argue that evolution of CSR implementation managers' role from one where they were considered to be a 'giving manager' with a primary role of handling charity support requests and managing a basic giving process to one where they are more heavily involved and influential in CSR policy development and reporting shows an increase in strategic importance of all CSR-related activities within the organization-and central to this is stakeholder management and issue cognition.

In the following section, we will argue that what has evolved in many firms is a CSR giving process that begins to exhibit the characteristics of a dynamic capability which assists in stakeholder management and provides the firm with a sustained competitive advantage. Porter (1991) states that business processes are the source of competitive advantage, and Ray et al. (2004) state 'that business processes that exploit intangible firm resources are more likely to be a source of competitive advantage than business processes that exploit tangible firm resources'. For these reasons, we view the CSR giving process as a resource that can be developed into a dynamic capability. Developing dynamic capabilities is in essence an acceptance of the resource-based view (RBV) of the firm where firms acquire and control rare resources and then use them to develop a sustainable competitive advantage. In Barney's (1991) seminal paper, the goal of management was to utilise its resources in a manner which allows them to implement and carry out the firms' strategy in the pursuit of a competitive advantage. Oliver (2000) stresses that the one true sustainable in the modern world is that any 
competitive advantage will be temporary, but suggests that corporate learning can be one of the most enduring sources of competitive advantage.

Central to RBV is the classification of resources as possessing value, being rare amongst their competitors, being imperfectly imitable and not having substitutes. Such a classification was subsequently developed by Barney (1995) into the VRIO framework which is a tool designed to better assist in the analysis and management of the firms' internal resources in achieving their strategic goals. This theoretical perspective has guided much managerial action in the past, and this approach holds distinct advantages for understanding the qualitative findings from our research. However, while we agree with Kraaijenbrink et al. (2010) in their recent review and detailed critique of the RBV of the firm, that RBV is not strictly a theory of the firm, it is a useful conceptualization which assists management better understand and make more effective use of the firm's resources. By focussing on this view of the firm, we argue that firms who have engaged in CSR giving as part of their overall CSR policy have implicitly accepted the resourcebased logic of the firm and can see a return (tangible and/or intangible) to the firm.

\section{Developing the CSR Giving Process into a Dynamic Capability: A VRIO Perspective}

Capabilities are 'information-based, tangible or intangible processes that are firm specific and are developed over time through complex interactions among the firm's Resources' (Emphasis in the original) (Amit and Schoemaker 1993, p. 35). Being firm specific necessarily defines capabilities as being embedded in the organization and its processes, and being embedded suggests that they are, therefore, not easily transferable and are an asset of the firm. Teece et al. (1997) suggest this means that capabilities must be specifically created by each firm, and Makadok (2001) comments that this means a manager's role may be analogous to an architect, designing and developing capabilities that their particular firm requires, using the resources available to them. Eisenhardt and Martin (2000) define dynamic capabilities as a set of specific and identifiable processes that have significant commonality in the form of best practices across firms, allowing them to generate new value creating strategies and which also vary with the level of market dynamism and allow an organization to adapt to changes in the business environment. It is this, the best practice element (CSR giving) which emerges from our research and is discussed in detail later in this paper and we provide Table 2 (Evolution of CSR to being a dynamic capability) as our interpretation of best practice based on a review of the literature and our respondents' comments. In the following section, we apply the VRIO framework to the CSR giving process, thus emphasising CSR giving's potential to be a dynamic capability.

\section{The VRIO Framework and the CSR Giving Process}

To determine whether or not at least theoretically a sustained competitive can be created by the organization investing resources into the CSR giving process, we use Rothaermel's (2013) approach to understanding the VRIO framework's applicability to the firms CSR giving process (c.f. Barney 1991) where we firstly determine if the CSR giving capability meets four necessary criteria, is it Valuable, Rare, Costly to Imitate, Organized to Capture value (VRIO):

1. Is the CSR giving capability valuable? We can ask does a CSR giving capability add value by enabling a firm to exploit opportunities or defend against threats? If yes, the CSR giving capability should be considered valuable.

2. Is the CSR giving capability rare? Can it be easily obtained in the marketplace? Resources that can only be acquired by one or very few companies are considered rare. Rare and valuable resources grant temporary competitive advantage.

3. Is this CSR giving capability costly to imitate? A resource is costly to imitate if other organizations that do not have it can not imitate, buy or substitute it at a reasonable price. A firm that has valuable, rare and costly to imitate resources can (but not necessarily will) achieve sustained competitive advantage.

4. Is the capability Organized to capture value? A firm must organize its management systems, processes, policies, organizational structure and culture to be able to fully realize the potential of its valuable, rare and costly to imitate CSR giving capabilities. Only then the companies can achieve sustained competitive advantage.

A VRIO perspective enables management to view the CSR giving process as one that can provide the firm with a sustainable competitive advantage if the effective management of stakeholders and salient issues that occur are viewed as an intangible asset for the firm. As a result of the research noted above, we explore in this paper the following research question:

RQ: Can organizations manage salient stakeholder relationships more effectively by developing dynamic CSR giving capabilities?

It is through answering this research question that we contribute to the field by making several contributions, both theoretical and managerially oriented: 
1. Our first theoretical contribution is that to our knowledge, we are the first researchers to apply and empirically validate the newly proposed Strategic Cognition Framework for Issue Salience (Bundy et al. 2013) in a CSR context. The framework is proposed as a way for management to better understand the key issues relevant for their firm when prioritizing stakeholder concerns and requests. By drawing heavily on stakeholder theory and conceptualizing that management should view the world from an organizational identity, and a strategic perspective, it allows managers to plot on a grid where an issue lies and whether or not it is high, moderate or low in salience. Managers can then take action to respond to these highly salient issues, and our paper focuses on the process of CSR giving as this managerial response. We provide empirical support for the framework and show that it has managerial relevance in the context of CSR giving.

2. Our second contribution is that we expand upon Munilla and Miles (2005) suggestion that 'a strategic CSR perspective helps immunize the firm from subsequent pressure ... and allows the firm to exploit its investments in CSR for the development of distinctive competencies, resulting in superior, sustainable performance' (p. 385). We show that some companies are organizing their CSR giving in a manner that provides them with VRIO capabilities which can lead to a competitive advantage in the form of stakeholder management.

We provide evidence that many of the respondent firms are clearly developing CSR giving and suggest this could progress to be a dynamic capability of the firm, even though they are not calling it a dynamic capability. We regard the CSR giving process as the dependent variable of our study; this is different to the traditional view of resources as being tangible in nature. The managerial decisions taken relating to supporting the firms CSR giving process provides evidence that a resource-based view of the firm is the dominant logic within the firm and that there is an expectation of a return to the firm, albeit relatively intangible in nature. Organizational resources were being provided to better support the CSR giving process and in the majority of cases once begun the CSR giving process gains momentum and evolves into a far more sophisticated and professional process, tying in more effectively with the firms overall CSR strategy.

3. Our final contribution is a managerial focussed one, where we develop a 1 page summary Table (Table 2 in Appendix) showing the varying levels of sophistication in CSR giving processes through the lens of Peters and
Waterman's (1982) McKinsey 7S strategic framework. We have developed this table from best practice drawn from the literature and supplemented it with evidence from our research. This table allows managers to assess the state of play of their own CSR giving process relative to those companies who are more advanced in the area.

\section{Methodology}

The purpose of this study was to gain an understanding of the giving behaviour of large corporations and also to examine the elements of that behaviour that might lead to better implementation methods and processes. The conceptual approach to the research design follows the processes developed by Creswell (2003), that is, qualitative-based primarily on constructivist perspectives where 'the multiple meanings of individual experiences, (and/or) meanings socially and historically constructed, with an intent of developing a theory or pattern' (Creswell 2003, p. 18). There have been few comprehensive studies of corporate support of charities from a qualitative perspective that move beyond aggregate statistics or surveys.

In order to fully understand corporate support by large organizations a deeper and richer study is required than that suggested by a positivist and deductive approach, as identity and meaning of data must be obtained through a study of the complex web of relations that define the situation (Hesse-Biber and Leavy 2006). Instead of commencing with deductive theory, inductive reasoning progresses from the 'bottom' up; moving from specific observations to broader generalizations and conclusions. By its very nature, it is more open-ended and exploratory (Hesse-Biber and Leavy 2006). Inductive reasoning begins with knowledge gathering and data gathering, with the results then subject to enquiry and analysis to detect patterns and regularities. Themes are then developed from these patterns, with the researcher moving back and forth between the data and the themes to develop a comprehensive set of themes (Creswell 2007) which then form the basis of some general conclusions, models or conceptual frameworks (Blaikie 2000).

The research commenced with a thorough review of the literature to properly understand the information that was published and known at that time and to stimulate theoretical sensitivity (Strauss and Corbin 1998). The data gleaned from this initial literature review were used to develop a form of skeletal framework for the field research that was undertaken (Miles 1979). From this initial research and the framework developed, it could be seen 
that the practice of corporate support is changing, especially in large organizations, often being related directly to CSR. It was also evident that is being driven to change by the stakeholders of the firm.

Different social actors may understand social reality differently, producing different meanings and therefore analysis (Hesse-Biber and Leavy 2006), thus it was necessary to ask the corporate managers involved how and why they make the decisions they do. Gubrium and Holstein (2001, p. xi) recommend interviews as 'the method of choice for obtaining experiential information from individuals' and in-depth semi-structured interviews were the method selected for this research. Large corporations, defined by the Australian Bureau of Statistics as those having more than 200 employees (ABS 2002), were chosen as they were considered to be more likely to have systems and structures in place in implementing CSR and have different implementation strategies to small organizations (Lindgreen et al. 2009). Most of the prospective companies were drawn from companies on the 'S\&P/ASX 200', a register of Australia's top 200 stocks by market capitalisation (S\&P 2013). Several large foreign-owned companies were also included in the data set to confirm that Australian companies were not using CSR processes significantly different to other companies operating in Australia, with the data confirming they were not acting in dissimilar ways. As the manager needed to have primary day to day responsibility for the management of their program, the individual managers were thus purposefully selected on the basis of being a manager in a large organization operating in Australia that had an active charity support program in place.

Initial contact with the prospective interviewees was predominately by telephone as prior industry experience had shown that the results obtained would be improved with this technique. Several other initial contacts were made at a nonprofit marketing conference. In every instance, the initial manager interviewed was embedded in their company's CSR program. For several companies, the initial interviews and additional research were insufficient to properly gain a full understanding as there was a multitiered giving structure in these organizations, and with the initial manager's knowledge, a second manager was interviewed from each company in order for the data set to be more complete.

There was no pre-determined number of giving managers to be interviewed. Kuzel (1999) notes that the sample size in a qualitative study is typically small, 'between 5 and 20 units of analysis' (p. 34), Gaskell (2000) suggests that there is a practical limit to data management of between 15 and 25 interviewees, while McCracken (1988) suggests as few as eight can be sufficient and Miles and Huberman (1994) find twelve to be an acceptable number. The sample size was determined on the concept of theoretical saturation (Creswell 2007), that is, interviews continued until no significant new concepts emerged from several interviews. In total, 23 companies formed the data set and 26 interviews were undertaken. Table 1 (Appendix: General information on the respondent companies in this research) provides information on these companies. This is general only as anonymity was a condition of the interviews. Informed consent to be interviewed through a signed consent form was obtained before interviews took place.

Both the style and nature of the questions were built on an analysis of semi-structured interview techniques. The design concept was to ask fewer, broader questions and let the participants mostly carry the interview, with the researcher probing on topics requiring clarification. At the time of the interview, all but one of the managers consented to a tape recording of the interview. This one manager requested that only notes be taken during the interview and this was done, with a recording made by the researcher immediately after the interview. Notes were taken in all interviews to assist in information recall as to the intent of sections of the conversation. The recordings were then transcribed word for word by professionals who specialise in transcription. The early transcriptions were immediately audited against the actual recording by the researcher to ensure accuracy of the transcription process. Later transcriptions were checked against the original recording over time. With the exception of some industry jargon the transcription quality was generally excellent.

Once all of the interviews were initially read the list of ideas, clusters of topics and themes were studied, and the overall list of ideas and themes was distilled and reduced by merging similar concepts into general categories Creswell (2003). Coding was done by the interviewer and the use of a single coder enhances the internal credibility of the coding framework through consistency of coding (Milne and Adler 1999). From the content analysis (Patton 2002) of these interviews and by coding the data for key thematic patterns and relationships (Miles and Huberman 1994), several keys issues and concepts emerged.

\section{Results and Discussion}

Stakeholder Saliency ("Who”' is Important)

Every CSR implementation manager interviewed was able to nominate their most important stakeholder group or groups. The research suggests this corporate manager also knew who the Board and CEO viewed as important stakeholders and this understanding guided their actions. Importantly, they were all a part of what Maon et al. (2008, 
p. 418) describe as necessary for "CSR convergence", that is the 'CSR integration loop' which is 'an established CSR committee or department'. Hill and Jones (1992) state it is the manager's perceptions of stakeholder influence that will determine which stakeholders are considered important. The CSR implementation managers always have multiple stakeholders in mind, even if they develop programs aimed particularly at a stakeholder or stakeholder group. Sen et al. (2006, p. 164) demonstrated that 'even a single real-world CSR initiative is capable of affecting both internal outcomes and behavioural intentions related to multiple stakeholder roles'. The range of stakeholders and the sometimes conflicting priorities is exemplified by the comments from these managers:

It engages stakeholders, so it's staff involvement stuff as opposed to just something that happens at the board table, it's about getting people more involved in issues ... but we do recognise we're part of the community (and) how we're seen by the community and what we do for the community (is important). (A3)

Licence to operate! (The company) is a mining company and can only continue to operate if the community and regulators allow it to. (C5)

When you've got your stakeholders ranging from - we list them in our (CSR policy) - customers, colleagues, suppliers and partners, shareholders and the communities that we live and work - there are always going to be tensions between what you do for one stakeholder and why, and they are the decisions we need to make. (C2)

Staff would probably be peak, absolutely peak, they are our key stakeholders (but) you know to operate in this environment; we need that social license to operate as well. We struggled a lot ... with politicians and the media, so I do a lot of political work, ... and the media ...... because they don't want to write good news stories about (the industry). (B1)

The managers were interpreting CSR policy and developing programs based on their interpretation of salient stakeholders and the requirements of their CSR policy and strategy. Interestingly, shareholders were only infrequently nominated as the most important stakeholder although most managers specifically recognised them as having legitimate and legislated power, and most included them in their second tier of nominated stakeholders. From Mitchell et al.'s (1997) findings on stakeholder saliency, in suggesting it is the firms' managers who determine saliency, and therefore, 'the degree to which managers give priority to competing stakeholder claims' (p. 854), the managers were specifically asked about which groups they perceived as being most important to them and their organization. An evaluation of their understanding of salience combined with a general appraisal of the company and of industry each organization operates in became a useful exercising in understanding their responses.

The managers were able to describe how their CSR support programs were predominately focused on those stakeholders considered as salient and how the programs were developed and implemented with those stakeholders in mind. This rich description overcomes some of the limitations imposed in previous studies-that of researchers making assumptions of stakeholder pressure. The first decision the manager made was that of determining the salient stakeholder group(s), and CSR support activities were guided by this determination. CSR is becoming a strategic tool aimed at stakeholders in order to assist in securing their support for the organization, or to counter objections they might have, now or in the future.

\section{Strategic Cognition and Issue Salience ("What" is Important)}

While the CSR implementation managers spend significant time in trying to understand who is important, that is who their salient stakeholders are; they also must attempt to understand what is important for the organization. Strategic CSR has been demonstrated as being more effective as a longer term investment (c.f. Burke and Logsdon 1996) and is an investment in the long-term future of the organization (Porter and Kramer 2006). This was recognised by the CSR implementation managers, with all (100\%) of them mentioning 'longer' timeframes as being preferred for their programs. The following excerpts provide examples of this:

.... going for that long term impact, certainly not a one off campaign or a one off idea it's very much about an ongoing sustained commitment (A9)

I tend to recommend three years to the (company) when I find these partnerships .... we look at a three year term, review it after about 2.5 years. (A4)

we've had a quite long-term relationship with (nonprofit organization) .... it's been just over 10 years, .... I think that when they've done a review of the program, well before my time, it was decided that it was still a very good program ... there is another one (that) has been about a 10 or 11 year partnership .... the reason you want a long-term partnership is you've got some continuity. (C3)

They need to have relevance for us and some of the things that we look at for our relevance is geographic relevance .... long term relationships are very 
important for us. We also look at you know does it have a business relevance. (B2)

They also used their determination of their salient stakeholders when examining the issues to be addressed in the programs. There is little doubt that the two elements of stakeholder salience and issue are interconnected. Bundy et al. (2013) state that stakeholder salience has a significant influence on issue salience. They define issue salience as 'the degree to which a stakeholder issue resonates with and is prioritized by management' (p. 353), and as noted above, that resonance is partly determined by the relationship of the issue with the strategy of the company and also with the desired organizational identity they wish to project. When using the Bundy et al. (2013) framework noted above (Fig. 1) it can be seen that many of the issues addressed by the CSR implementation are located in the Consistent strategic frame/ consistent organizational identity sector. These issues are perceived as having materiality and thus the firms commits 'substantial resources, time, energy and effort to the issue' (Bundy et al. 2013, p. 364).

This is not to say that all the issues identified by managers are consistent with the strategic frame or identity. When there is 'negative' connotation (through strategic frame or corporate identity issues) these are considered worth of attention. Several respondent companies involved directly or indirectly in high-profile extractive related industries can be seen to be using CSR giving to address issues in the high salience zone of Conflicting strategic frame and/or conflicting visions of corporate identity held by salient stakeholders.

Some extended example of this, using multiple extracts from the same manager, are described. This first manager described her position as:

"I'm the corporate affairs manager" .... "the branding and the corporate identity, I'm responsible for that" .... (and) "the sponsorships and donations form a large part of the role" (A6)

She described several issues that she has had to address for her company:

we've had a lot of issues with the timber industry. And when I first joined (the company), we'd had people with koala suits out the AGM with giant logs that were supposedly old-growth logs......and we never log anything. (A6)

This can be seen as what Bundy et al. (2013) describe as a 'True threat' $-a n$ issue that was inconsistent with the corporate identity and as raised by the protesters, was also inconsistent with the strategic frame of the company that processed timber (and many other materials). The response of the firm initiated by this manager is what is termed within the framework as 'substantive defensive', designed to distance the organization from the issue. She developed relationships with a nonprofit organization that was seem as 'light green' (that is not "more radical" in her terms), and projects that involved significant numbers of company and nonprofit staff and noncompany volunteers that lived locally to the company's production facilities to work on projects that addressed the issue of corporate identity within that strategic framework:

(the nonprofit) would be (coordinating) tree-planting projects, etc., ......, ' $\mathrm{X}$ thousand trees were planted. This much land was regenerated. What we found is (that) just because you work at a (facility), doesn't mean you live there (A6)

Not all the responses are directed at solving current issues. The same manager described her efforts and the results in developing a 'symbolic defensive' response. The stakeholder potentially sponsoring the issue in this case was the community around a production facility, with the threat posed by these stakeholders being that of potentially negatively influencing the operating conditions of the facility. The response is considered symbolic as the threat is to corporate reputation (organizational identity) only, and not the strategic frame of the company:

We're not perfect, and there'll be truck movements, and there's an occasional bit of pollution or something that happens....but I think if you're seen as a company that cares about the local community, that's coloured with that view in their (stakeholders) mind, isn't it? You might have had a chemical spill last week, but...... last year, (we) were dredging the creek and helping with the bushfire rebuilding or whatever, and I think people do sort of balance these things in their mind. (A6)

The manager from a different organization was also being proactive in the company's CSR programs. The company was involved in many areas of consumer products, including some that could be considered as 'harm' products:

It became a much more difficult one to think about what's the right way to go about and help this. And this is a really risky project from a PR perspective, in that we've got our people going into a ...... community, and I get people scoffing and saying, 'Oh, what's an ..... company doing....'(C1).

In this case, the issue is an example of Bundy et al. (2013) expressive salience quadrant, where the potential stakeholder issues were salient to organizational identity yet unrelated to strategic frames, as the organization would not make a decision to abandoned an industry (but were in fact expanding within it): 
You get that initial negative reaction before trying to understand what we're doing. The response from the CEO and everyone else, but the CEO first was there with such enthusiasm that this is the right thing to do. We can make a difference here. If this works, it can be a model for a whole lot of other communities, around how to do....the fact that we've got a lot of skills, expertise, just a whole lot at our hands that any small community doesn't have ...... so I just think it really helps to go beyond just giving some money to a few different charities when you've got people who really see the strategic long-term....how this can really just grow into something bigger. (C1)

Another example of expressive salience, with a 'symbolic accommodative' response is explained by this manager, who also notes the use of CSR for strategic purposes:

In fact I would call the whole lot of it strategic. We're looking at a long term vision of starting kids getting interested in science very early moving them through high school hoping that there's more kids who are interested in it which actually increases the pool of kids who want to go on and study fields like (........) and then hopefully we're capturing them at the other end to get them into an (........) degree. (C3)

From these findings, it can be seen that the framework developed by Bundy et al. (2013) has relevance for corporate managers. It can be used to reveal how the identity of the corporation wishes to project, and strategic frame of the organization influences the prioritization of salient stakeholder issues and allows consideration of the subsequent nature of the corporations responsive. The CSR implementation managers are, therefore, significant actors in stakeholder management in large organizations. How they perceive and understand stakeholder issues using the dual lens, or strategic framework, of corporate identity and corporate strategy leads these managers to using the internal processes and resources of the corporation in order to attempt to satisfactorily resolve stakeholder issues. It is these processes of CSR implementation that can lead to significant advantage for the organization. How these can lead to CSR giving being developed as a dynamic capability is discussed in the next section using the results of this research, supported by prior seminal research on corporate giving.

\section{CSR Giving: A VRIO Approach}

Peloza and Falkenberg (2009) show that the success of CSR is dependent, at least partly on how effectively the CSR initiatives are executed. This demonstrates the importance of process as it is the process that significantly influences the execution of any initiative and it is the process that is the dynamic capability. A VRIO perspective is an effective tool to conceptualize the use of corporate resources and processes in order to develop the CSR giving process as a competitive advantage. As outlined earlier in the paper, Barney (1991) identified four attributes that firm's resources must possess in order to become a source of competitive advantage. In a CSR context, there are:

\section{Is the CSR giving capability valuable?}

The most common questions to answer in order to demonstrate if a capability is valuable revolve around the concepts of reputation, recognition and value. Many researchers attribute the motivation for CSR to corporate reputation, for example Maignan et al. 2005, p. 974) state 'Far from being a luxury, CSR has become an imperative to secure stakeholders' continued support, and ensure a desired identification and reputation among customers, employees, shareholders, NGOs, and governments'. Others suggest companies are strengthening their reputations through CSR (c.f. Fombrun 2005) and that communicating CSR efforts and activities can improve corporate reputation (c.f. Eberle et al. 2013). A study by Godfrey et al. (2009, p. 442) concluded that 'good deeds appear to earn chits. The results indicate that managers of firms who engage in CSR activity can create value at times for their shareholders through the creation of insurance-like protection'. Lai et al. (2010, p. 466) demonstrated that 'that CSR effect on brand performance is partially through the effects of corporate reputation' and Lange et al. (2011) also suggested a good reputation can help overcome negative information received by stakeholders. There is no doubt that CSR implementation managers believe there is a direct connection between good CSR implementation and reputation, with $82 \%$ of the managers when asked why their company was involved with CSR, believing the company used CSR for this purpose. Where CSR giving is also of significant value to the organization is in their relationship with their employees. In many of the respondent companies it is the CSR expectations of employees and their involvement in the CSR giving (for example donations and volunteering) that drives the process. Several authors suggest that CSR, employee retention and recruitment and better relations lead to more productive workplaces (c.f. Sen et al. 2006; Brammer et al. 2007). The following extracts from the transcripts describe this well:

Primarily I look after our CSR program .... to ensure that there are three main areas which the program is the purpose of the program is ...(number one is) to engage our employees; number two is strengthening to build our brand reputation, as well as (number) three, strengthen our business. (A10) 
So you get your employee engagement, which is important, and it's good from a reputational perspective. (C1)

(Our guidelines for any program say) Support must show a broad benefit to the community and Must be "profiling building" for (company) in the local or wider community ...... (to) Improve corporate reputation (C5)

the integrity is very important. They don't have to be very well publicly known, but the reputation is important. (C1)

In addition, $56 \%$ of the interviewed managers said (unprompted) they would not be involved in any CSR activities that would harm the reputation of the firm. The negative, of not wanting reputational harm was also mentioned:

we wouldn't support anything that e.g. would appear to harm the company's reputation (C4)

The managers were focusing on the future as well as the present, looking to minimise future risk, for example as this manager explains:

Plus they wanted in this day and age they really want to be involved with people that are not going to bring negative media or reputation (A4)

Picking up awards for the CSR activities was seen by those (few) who mentioned the subject was seen as a part of communication-something that was a valuable adjunct and necessary for stakeholders to be aware of, as this manager explained:

Of course, we like to win awards, so we do apply for various awards when they're going ..... we won the Partnership of the Year award ... we were just absolutely gobsmacked when we won that. And so that's really helped us communicate the partnership. (A6)

From an employee engagement perspective, many managers reported providing programs and benefits that assist in employee retention, recruitment and better internal stakeholder relations such as:

An employee has to work for the company for 12 months. Then they're eligible to apply for a community grant, where the employee has to volunteer a minimum of $50 \mathrm{~h}$ a year to the group or the charity and it as to be a project so we don't just give (untied) cash $\ldots$ up to $\$ 5,000$ maximum for teams and $\$ 3,000$ for an individual. (B2)

The volunteering part of that is any time a (company) employee gets involved in a community group whether that's through a personal volunteering day or team volunteering day or through a structured mentoring program. Every(company) employee gets two volunteering days per year and they can volunteer for any charity they choose. (Participation rate) it's almost 50 percent (A9)

I developed a group of sustainability ambassadors, various people at all sorts of levels across the business, who (were) interested in volunteering at particular sites - to be the person on the ground to generate new ideas, give feedback around what needs to be done, and implement issues that we were driving down from the top. (C1)

The best value is a value that the salient stakeholder recognizes (Walters and Lancaster 2000) and using stakeholder identification and prioritization (Hill and Jones 1992), combined with the Bundy et al. (2013) issue prioritization framework should help managers optimize their value creation. In CSR implementation, value is created by developing a companywide system including communication of the processes and the rewards system centred upon managing the relationship with the salient stakeholders.

\section{Is the CSR Giving Capability Rare?}

The typical method of measuring rarity of a capability involves asking the questions of whether or not the company has a capability that others do not, or that others cannot bring to the market easily. Giving money to charities is not rare, however, having the personnel, systems and structures in place to do it well is rare. As there are few tertiary qualifications directly available in CSR, in contrast to established professions such as accounting, marketing and engineering, all of which also have formal certifying bodies, many of the CSR implementation managers have learned by doing, and therefore, their experience is rare. In addition, when asked, every CSR implementation manager believed they needed improvement in their processes. They understood companies were at different stages of implementation of CSR and believed there was a great deal of organizational learning that was occurring in their company and that this was ongoing.

The excerpts below highlight the different stages that companies were at when interviewed, and it can be seen that some were just beginning (12 months into the process, even though they were a large successful company), some were developing systems to help inculcate CSR through the organization, and some companies had what could be considered very mature CSR programs:

My role in corporate affairs is to, from a group level, look at where we sit in the community. At the moment I'm just trying to build the function from the ground up, you know it's a little bit.. (daunting). (A7) 
Give them (SBU's) some structure around that ... here are the types of programs that we want to support; here are the types of charities that you can support within that space. It does just start to engrain this that this is just this is (company) best practice so to speak (A9)

So I went out and talked to sort of find what the best practice was, spoke to other (companies) so you know in that sector even though we got competitors you know (they were) very keen to talk, everyone. I spoke to a lot of them as part of that process I also spoke to (an associated company) in (USA). (B8)

The excerpt from the interviews quoted below is from a company that has a balanced focus to the CSR giving, with both internal and external stakeholders considered to salient to this company. Their CSR implementation practices and processes were arguably among the most advanced of those in the respondent companies:

H.O. manages the corporate programs. The (corporate) Community Relations team basically decide the rules and guidelines, including for outcomes. There are 4 people at HO plus (1-2) people in each region looking after our relationships. A committee from each state works out the details of the workplace giving programe. Employees can volunteer up to one day per year, with full pay, with a community group of their choice. (A5)

\section{Is the CSR Giving Process Costly to Imitate?}

Supporting (Maon et al. 2010), who provide a framework showing the evolution of CSR culture and implementation, we found that CSR giving involved having a corporate strategy, corporate commitment, the correct people to lead and develop the processes, and 'buy-in' and respect for the process throughout the organization, technology to capture and report information enable automation of support processes such as direct employee donations from wages and gift matching etc. All of this takes corporate resources, the least of which are corporate dollars. Barney (1991) states that a capability is costly to imitate if other organizations can not imitate, buy or substitute it at a reasonable price and capabilities that developed over a long period usually are costly to imitate. Our respondents often stated that they were not the initiating managers of CSR giving or the broader policy, but that they had stepped into an existing role or structure which had been around for often numerous years, with prior investments are organizational time and commitment. The following excerpts demonstrate the considerable people hours and resources they have invested in doing so:
(Our 15 regional people) come in once a year for two days and we (with 5 from $\mathrm{HO}$ ) do a business planning workshop. Prior to coming in they are given a set of questions and they will go and talk to the employees in their region and say what did you like in the last 12 months, what didn't you like, what would you like (us) to provide for you over the next 12 months. (B2) I formed a sustainability leadership group, which was key functional people in senior roles in Australian and New Zealand. So we would all get together and we met monthly ... to talk about what the key issues were, what the priorities were, make sure there was information sharing, and develop strategy. (C1)

\section{Is the CSR Giving Capability Organized to Capture Value?}

For a capability to capture and deliver value there has to be an organizational intent to use it in some way for a return and in this case it is the intention to use CSR giving to meet stakeholder expectations. This intent is captured in formal CSR strategy policy where the goals and expectations of a return are articulated. The following sections show that in the case of CSR giving, where the returns are mostly intangible in nature, determining CSR policy and the expectations of a return, how to measure any return to the firm, how to communicate their CSR giving to stakeholders, requires considerable internal process and structural development. The CSR implementation manager is often involved in all of these activities especially in determining the structure of the CSR function within the organization:

(My role is) not just doing the implementation of the CSR activities and the program but also set the direction, put forward strategy, make sure that it is aligned with the company's business priorities (A10)

Sustainability for us covers....there are three main pillars that it generally does, which are social responsibility, environmental responsibility, and the economic sustainability of the business. So we're looking at that holistically. My role is more strategic across the group, looking at all of that. I've been in the role for two years, and it was a newly-created role. We've been a lot in the space of all those three areas for a long time, but it was spread across the business and not one person $100 \%$ dedicated to all of those issues. So that was my role: to pull it all together. I was to develop a strategy in relation to this. (C1)

Charity giving anywhere in an organization is often reported as CSR, but in companies with more advanced processes, regional managers for example still had some responsibility for CSR giving, and some of that was provided for totally 
local stakeholder reasons but the significant difference was the integration of the support with a companywide CSR and CSR giving strategy. They were making decisions locally as a part of an integrated strategy for the betterment of the whole company with organizational structures having been designed over time to use this CSR giving capability and there were excellent CSR specific management and control systems for this capability.

After the strategic aspects of their role, the CSR implementation manager is often responsible for setting up the corporate processes relating to value derived from CSR giving. Usually starting with determining the value of CSR giving, evaluating the return to the organization and reporting it to key stakeholders. In order to understand if a return is achieved it is firstly necessary to be able to define what would be considered as an organizationally legitimate return and then decide which is the best way to measure it (quantitatively vs qualitatively). One issue is that measuring the return from CSR is extremely difficult (Bhattacharya and Sen 2004; McWilliams et al. 2006; Barnett 2007), as these managers describe:

I would like to measure it and it's difficult because it is really, as you already know, it is incredibly qualitative. There are two things that I would like to properly measure; one is benchmark ourselves in terms of community support .... and then secondly is to measure the impact, going back to your first question, measure the impact on that community involvement on our business and on the community. It is really difficult; it is really, really difficult (A1)

Measuring .... how do you measure the success of our internal components? Is it through increased participation of employees? Whether they sign up to workplace giving?, whether there's more volunteers?, more volunteering days being taken? etc., etc. (A10)

In our results $73 \%$ of the CSR implementation managers interviewed commented they were not actively or formally measuring the outcomes they would like, or even if they should, measure for outcomes:

Measuring .... how do you measure the success of our internal components? Is it through increased participation of employees? Whether they sign up to workplace giving?, whether there's more volunteers?, more volunteering days being taken? etc., etc. (A10)

The firms with more advanced CSR giving processes used some formal methods such: (1) staff CSR awareness survey-36 \%, (2) the degree of employment involvement in volunteering-36\%, (3) employees involvement in donations-23\%, (4) the extent of media coverage$27 \%$ and (5) community awareness surveys-23\%.
To assist in measuring outcomes, four companies reported they had looked at the London Benchmarking Group (LBG) process as a method of measuring outcomes, and two had proceeded. This supports the findings of Ahmad et al. (2010) who reported most companies who report charity support activities do not use the LBG model. The managers in organizations that had commenced using LBG suggest that the LGB process, while very useful, did not capture all of their support, with one manager reporting:

Well for London Benchmarking group it's kind of like there's so many things that are happening around (the company). A lot of community activities and support and it was just a good tool to sort of consolidate everything and just kind of try to capture that. And actually trying to - maybe also it's a bit of proof to the executive and the board to say, this is not a nice to have, this is an essential to have a CSR program in place. (It) captures as much as it can but I'm sure that there's others (charity support activities) that are slipping through the cracks. It just sort of just spotlights and it consolidates in your head because there's so much stuff going on around the business (A10)

While measuring outcomes presents difficulties for numerous firms, the reporting and subsequent communication of their CSR giving is an important process:

We report in the Annual report, Sustainability report, Employee newsletter, Industry forums (e.g. 2 day event with 50 business and community leaders), Press releases, Notice and information on Web site (A5)

If you look on the (international corporate) website there are various areas particularly .... under sustainability section, and some of our data is incorporated in that. (C2)

The reporting methods most commonly mentioned were: the inclusion of relevant reporting within the company annual report (41\%) and the inclusion of the NPO support programs in some form on the company web sites (also $41 \%$ ). Other common methods of communicating CSR giving by the company to external stakeholders included sustainability reports, community reports, press releases and (5) CSR reports.

These reporting activities show that there is considerable effort within the firm to capture the value of CSR and communicate it to key stakeholders, especially employees. Of interest is the extent to which the more advanced firms performed this activity:

Media response is measured by our agency - they put a dollar value on all of it. We survey our customers and our staff. We have a data base of all the applications, support, amount of publicity and media, 
survey results, staff involvement etc. Branches also provide written feedback on their programs. (A5)

If CSR giving is to be a source of sustained competitive advantage, the VRIO framework is a useful method of evaluation. Value is provided in increasing the reputation of the firm and in managing salient stakeholders. The rareness of the capability is obtained by integration of the strategy of CSR combined with the sophistication of the corporate processes to successfully implement CSR giving. It is these processes, developed over significant time that captures the value to the organization and makes it difficult for 'newcomers' to imitate.

\section{CSR Giving Implementation: From a Basic Function to a Dynamic Capability}

An outcome of this research with managerial benefit is our Table 2 in Appendix which we hope allows managers of all levels to assess the state of play of their own CSR giving process relative to those companies who are more advanced in the area. This will assist managers wishing to improve the effectiveness of their giving programs by highlighting the internal elements of the company that require improvement in order to develop CSR giving into a dynamic capability. We have developed this table by reviewing best practice drawn from the literature and supplementing it with evidence from our research. The table is presented using the Peters and Waterman's (1982) model called the McKinsey's 7-S Framework which has been consistently used to demonstrate that substantial elements of the organization that need to be aligned if it is to be successful. The framework has rated well amongst senior managers on their actual experience on helping them to decide 'whether they have the corporate capabilities to achieve', to better 'understanding organizational functions', 'giving them a deeper understanding' of a situation and 'giving them a clearer picture of what they should do' (Wright et al. 2013, p. 102).

\section{Conclusions and Managerial Implications}

In this paper, we put forth a theoretical argument that the CSR giving process can be developed into a dynamic capability providing a competitive advantage and then provided evidence to support our views. Central to our argument is that the value of CSR giving is its intangible return to the firm through effective stakeholder management (internal and external) which allows the firm to execute its strategies more effectively in pursuit of its goals. Reputation is an accepted and valued intangible asset (Schnietz and Epstein 2005), and Vilanova et al. (2009, p. 64) state it 'becomes a driver not only to initiate CSR approaches in firms, but also to drive the process inside the company'.
Using the RBV view of the firm, our application of the VRIO framework shows that management is treating corporate reputation as a resource worth investing in using their CSR giving program. Not only is corporate reputation valuable for external stakeholders, it is in many of our respondent companies a critical aspect of the employee/company relationship, where employees were the initiators and major drivers of CSR giving. Our findings support the conceptual 'dual loop model' developed by Maon et al. (2008) and further support Helmig et al. (2013) who show that the employees of the company exert the strongest influence on CSR implementation, and suggest 'that acting in a socially responsible way with regard to employees in the firm (for example, positive word of mouth, employee loyalty, and retention' could be a source of competitive advantage (p. 19).

While stakeholder theory has been the most commonly used theoretical framework for understanding CSR's role in organizations, what has been missing from the literature is an approach for managers to conceptualize, prioritize and respond to often competing stakeholder concerns. By applying the Strategic Cognition Framework for Issue Salience to CSR giving, managers better understand the potential impact of issues they believe are salient and the implications of their decision making. The framework is a new theoretical development that specifically focuses on understanding on two of the most critical aspects of CSR, that of corporate identity and corporate strategy. We are the first researchers to empirically validate the Strategic Cognition Framework for Issue Salience as an appropriate tool for management to better understand CSR giving. This theoretical approach is needed as to date there has been little published on how organizations make CSR implementation decisions, and therefore, very little practical experience for CSR implementation managers, CEO's and company Boards on which to base their support decisions.

\section{Limitations and Recommendations for Future Research}

The main limitations of this research project are framed by the research conditions. Most companies are represented by a single respondent, albeit they were the manager that was the focus of the research. Interviewing other managers from the same organization would obviously increase the depth of knowledge about the decisions on the company. In addition, the interviews were conducted in four cities in Australia. Additional interviews with CSR implementation managers from around the world would assist in overcoming the geographic limitations of the research. As only large organizations were the focus of the research the results are only directly relatable to these organizations and applying the findings and the suggestions to other types of organizations may be applicable and useful but is outside the scope of this paper. In addition, it was obvious from the research that not all 
large organizations in Australia have CSR programs, and from research by others that situation also applies to other countries such as the USA (c.f. Lindgreen et al. 2009). This makes it impossible to generalise these results for all large organizations.

The results of this research specifically reported the views of the CSR implementation managers, and their views of CSR giving are sometimes different to the corporate views reported by other researchers who interviewed CEO's, finance managers and other similar executive managers (c.f. Sargeant and Crissman 2006). These differences warrant investigation, especially given the previously unreported level of involvement of the CSR implementation manager in the development of CSR policy and strategy.

Our findings also lead us to suggest that many managers require a more sophisticated approach to determining salient stakeholders of their organization to assist them in the process of selection, evaluation and justification when choosing a proposal from competing charities or when deciding whether or not to continue an existing charity support relationship.

In conclusion, this research project has provided much new information about the process of corporate support for charities, and in particular the specific corporate role that carries many different titles, that of the CSR implementation manager. Corporate support of charities is, we believe, significant and important to all participants, especially the companies themselves, their charity participants and society in general.

\section{Appendix}

See Tables 1, 2 and 3 .

Table 1 General information on the respondent companies in this research

\begin{tabular}{|c|c|c|c|c|}
\hline Industry sector (ASX descriptor ${ }^{\mathrm{a}, \mathrm{b}}$ ) & $\begin{array}{l}\text { Number of } \\
\text { employees }{ }^{c, d}\end{array}$ & Turnover $(\$ A, 000,000)^{\mathrm{c}, \mathrm{d}}$ & $\begin{array}{l}\text { Wholly Australian owned } \\
\text { or subsidiary of } \\
\text { multinational (MNC) }\end{array}$ & $\begin{array}{l}\text { Identifier used } \\
\text { within thesis }\end{array}$ \\
\hline Consumer discretionary & $1,000-5,000$ & $250-500$ & Australian & A1 \\
\hline Consumer discretionary & $5,000-10,000$ & $1,000-5,000^{\mathrm{e}}$ & Subsidiary of MNC & $\mathrm{A} 2$ \\
\hline Consumer staples & $\mathbf{\Gamma} 10,000$ & [10,000 & Australian & A3 \\
\hline Financials & $1,000-5,000^{f}$ & $250-500^{f}$ & Subsidiary of MNC & A4 \\
\hline Financials & $5,000-10,000$ & $5,000-10,000$ & Australian & A5 \\
\hline Materials & [10,000 & $1,000-5,000$ & Australian & A6 \\
\hline Commercial and professional services & โ10,000 & $1,000-5,000$ & Australian & A7 \\
\hline Commercial and professional services & $1,000-5,000^{\mathrm{f}}$ & $250-500^{f}$ & Subsidiary of MNC & A8 \\
\hline Real Estate & $1,000-5,000$ & $1,000-5,000$ & Australian & A9 \\
\hline Utilities & $1,000-5,000$ & $5,000-10,000$ & Australian & A10 \\
\hline Financials & [10,000 & $5,000-10,000$ & Australian & B1 \\
\hline Financials & โ10,000 & [10,000 & Australian & B2 \\
\hline Commercial and professional services & $1,000-5,000$ & $500-1,000$ & Australian & B3 \\
\hline Financials & $1,000-5,000$ & $1,000-5,000$ & Subsidiary of MNC & B4 \\
\hline Commercial and professional services & $5,000-10,000$ & $1,000-5,000$ & Australian & B5 \\
\hline Commercial and professional services & $1,000-5,000$ & $1,000-5,000$ & Subsidiary of MNC & B6 \\
\hline Diversified financials & $500-1,000$ & $500-1,000$ & Australian & B7 \\
\hline Commercial and professional services & $500-1,000$ & $1,000-5,000$ & Australian & B8 \\
\hline Consumer staples & $5,000-10,000$ & $1,000-5,000$ & Subsidiary of MNC & $\mathrm{C} 1$ \\
\hline Health care & $200-500$ & $250-500$ & Subsidiary of MNC & $\mathrm{C} 2$ \\
\hline Industrial & $5,000-10,000$ & $1,000-5,000$ & Australian & C3 \\
\hline Industrial & $5,000-10,000$ & $5,000-10,000$ & Australian & $\mathrm{C} 4$ \\
\hline Materials & $5,000-10,000$ & $1,000-5,000$ & Subsidiary of MNC & C5 \\
\hline
\end{tabular}

Anonymity was a condition of interview. Managers were interviewed in Sydney and Wollongong (NSW), Melbourne (Vic) and Canberra (ACT) ${ }^{a}$ GICS (Global Industry Classification Standard) Industry Sector is used (http://www.asx.com.au/products/gics.htm accessed 4th December 2011) ${ }^{\text {b }}$ Companies that have been involved in a merger, take over, or subject to a significant change in circumstances since the interview are described as applicable at the time of the interview

c Latest available as at December 2011

d Australian operations, except where noted

e Asia-Pacific data available only

${ }^{\mathrm{f}}$ Interpolated from consolidated company data and regional percentages 
Table 2 Evolution of CSR to being a dynamic capability

\begin{tabular}{|c|c|c|c|}
\hline & $\begin{array}{l}\text { Low CSR giving sophistication/ } \\
\text { "charity giving” }\end{array}$ & Stepping stones or milestones & Dynamic CSR giving capabilities \\
\hline Strategy & $\begin{array}{l}\text { No strategy } \\
\text { Responsive only } \\
\text { Marketing driven }\end{array}$ & $\begin{array}{l}\text { Significant: } \\
\text { Competitive pressure } \\
\text { External stakeholder pressure } \\
\text { Internal stakeholder pressure } \\
\text { Adverse publicity }\end{array}$ & $\begin{array}{l}\text { Sophisticated and integrated with general } \\
\text { corporate strategy Driven by Board/CEO } \\
\text { Implementation manager involvement in strategy } \\
\text { and policy development }\end{array}$ \\
\hline Structure & No formal structure & Company Director responsible for CSR & $\begin{array}{l}\text { Integrated throughout organization } \\
\text { Formalised management reporting structures }\end{array}$ \\
\hline Staff & Local management responsibility & $\begin{array}{l}\text { Appointment of a manager with companywide } \\
\text { responsibility (initially often fractional) } \\
\text { CSR included in all job descriptions }\end{array}$ & $\begin{array}{l}\text { Dedicated CSR implementation manager(s), } \\
\text { Regional/SBU Sub-committees, } \\
\text { Employee Representative involvement in strategy } \\
\text { Many (fractional) CSR staff throughout the } \\
\text { organization }\end{array}$ \\
\hline Skills & $\begin{array}{l}\text { General management only } \\
\text { Training in charitable giving laws }\end{array}$ & Training in CSR and CSR reporting & $\begin{array}{l}\text { Public or media relations backgrounds } \\
\text { Knowledgeable and skilled in CSR }\end{array}$ \\
\hline Systems & $\begin{array}{l}\text { No special information capture or } \\
\text { reporting processes }\end{array}$ & $\begin{array}{l}\text { Information in annual reports and thus being } \\
\text { demanded in managerial reports } \\
\text { IT systems upgraded to capture information. } \\
\text { Development of collaborative capacity }\end{array}$ & $\begin{array}{l}\text { Sophisticated IT } \\
\text { capturing, filtering and coordinating requests } \\
\text { donations deducted from pay, gift matching, } \\
\text { reporting } \\
\text { Sophisticated reporting structures and } \\
\text { dissemination of activity } \\
\text { annual reports, CSR/sustainability reports, } \\
\text { internal reporting } \\
\text { Integrated with other corporate communication }\end{array}$ \\
\hline Style & $\begin{array}{l}\text { Ad hoc/responsive, not proactive } \\
\text { CSR as risk management }\end{array}$ & $\begin{array}{l}\text { CSR accepted as a strategic tool } \\
\text { Raising CSR awareness within the corporation }\end{array}$ & $\begin{array}{l}\text { CSR used as strategy and recognised as a } \\
\text { corporate competency } \\
\text { CSR as a substantive outcome (rather than } \\
\text { symbolic) }\end{array}$ \\
\hline $\begin{array}{l}\text { Shared } \\
\text { Values }\end{array}$ & $\begin{array}{l}\text { Local managerial issues and values, } \\
\text { may or may not be corporate values }\end{array}$ & $\begin{array}{l}\text { Corporate CSR strategy developed and } \\
\text { transmitted/integrated through corporate } \\
\text { policy }\end{array}$ & $\begin{array}{l}\text { CSR accepted as a Raison d'être, institutionalized } \\
\text { and enduring throughout the organization } \\
\text { Accepted as sincere by salient stakeholders. }\end{array}$ \\
\hline
\end{tabular}

Developed from research findings and Maon et al. (2008, 2009, 2010), O’Riordan and Fairbrass (2008), Aguinis and Glavas (2013), Smith and Bartunek (2013)

Table 3 Table of abbreviations and explanations

\begin{tabular}{|c|c|}
\hline Abbreviation & Explanation of abbreviation \\
\hline ABS & Australian bureau of statistics — the national statistical agency of the Australian Government \\
\hline CEO & $\begin{array}{l}\text { Chief Executive Officer-the highest-ranking executive officer in charge of total management of an organization. Includes the } \\
\text { terms Managing Director and Chief Executive }\end{array}$ \\
\hline CSR & $\begin{array}{l}\text { Corporate Social Responsibility-ISO } 26000 \text { suggests it is corporate action that contributes to sustainable development taking } \\
\text { into account stakeholders and complying with legal and behavioural norms. (ISO 2013) }\end{array}$ \\
\hline LBG & $\begin{array}{l}\text { London Benchmarking Group-developed a model to allow a company's overall contribution to the community to be taken into } \\
\text { account. Includes cash, time and in-kind donations, management costs and records the outputs and longer-term community and } \\
\text { business impacts of corporate community projects }\end{array}$ \\
\hline $\begin{array}{l}\text { S\&P/ASX } \\
200\end{array}$ & The S\&P/ASX 200 is a list compiled by Standard and Poor's of Australia‘s top 200 stocks by market capitalisation \\
\hline
\end{tabular}




\section{References}

ABS. (2002). 8157.0 Generosity of Australian Businesses [Online]. Retrieved April 7th 2013 from:http://www.abs.gov.au/Ausstats/ abs@.nsf/0/FD2DB957480CA60FCA256C2100076CB7?Open.

Aguinis, H., \& Glavas, A. (2013). Embedded versus peripheral corporate social responsibility: Psychological foundations.

Industrial and Organizational Psychology, 6(4), 314-332. Ahmad, R. A. R., Tower, G., \& Van Der Zahn, M. (2010). Communication of corporate philanthropy. 2010 AFAANZ Conference. Christchurch, New Zealand: Accounting and Finance Association of Australia and New Zealand.

Amit, R., \& Schoemaker, P. J. H. (1993). Strategic assets and organizational rent. Strategic Management Journal, 14(1), 33-46.

Barnett, M. L. (2007). Stakeholder influence capacity and the variability of financial returns to corporate social responsibility. Academy of Management Review, 32(3), 794-816.

Barney, J. B. (1991). Firm resources and sustained competitive advantage. Journal of Management, 17(1), 99.

Barney, J. B. (1995). Looking inside for competitive advantage. The Academy of Management Executive (1993-2005), 9(4), 49-61.

Bhattacharya, C. B., \& Sen, S. (2004). Doing Better at Doing Good: When, why, and how consumers respond to corporate social initiatives. California Management Review, 47(1), 9-24.

Birch, D., \& Littlewood, G. (2004). Corporate citizenship: Some perspectives from Australian CEOs. The Journal of Corporate Citizenship, 16, 61.

Blaikie, N. (2000). Designing social research: the logic of anticipation. Malden, MA: Polity Press.

Brammer, S., \& Millington, A. (2004). Stakeholder pressure, organizational size, and the allocation of departmental responsibility for the management of corporate charitable giving. Business and Society, 43, 268-295.

Brammer, S., Millington, A., \& Rayton, B. (2007). The contribution of corporate social responsibility to organizational commitment. International Journal of Human Resource Management, 18, 1701-1719.

Brammer, S., Pavelin, S., \& Porter, L. A. (2009). Corporate charitable giving, multinational companies and countries of concern. Journal of Management Studies, 46, 575-596.

Bundy, J., Shropshire, C., \& Buchholtz, A. K. (2013). Strategic cognition and issue salience: Toward an explanation of firm responsiveness to stakeholder concerns. Academy of Management Review, 38(3), 352-376.

Burke, L., \& Logsdon, J. M. (1996). How corporate social responsibility pays off. Long Range Planning, 29, 495-502.

Campbell, D., Moore, G., \& Metzger, M. (2002). Corporate philanthropy in the U.K. 1985-2000: Some empirical findings. Journal of Business Ethics, 39(1), 29.

Cantrell, J., Kyriazis, E., Noble, G., \& Algie, J. (2008). Towards NPOs deeper understanding of the corporate giving manager's role in meeting salient stakeholders needs. Journal of Nonprofit \& Public Sector Marketing, 20, 191-212.

Carroll, A. B. (1993). Business \& society: Ethics and stakeholder management. Cincinnati, Ohio: College Division, South-Western Pub.

Carroll, A. B., \& Buchholtz, A. K. (2000). Business \& society: Ethics and stakeholder management. Cincinnati, Ohio: South-Western College Pub.

Carroll, A. B., \& Shabana, K. M. (2010). The business case for corporate social responsibility: A review of concepts, research and practice. International Journal of Management Reviews, 12, 85-105.

Chen, J. C., Patten, D. M., \& Roberts, R. (2008). Corporate charitable contributions: A corporate social performance or legitimacy strategy. Journal of Business Ethics, 82(1), 14.
Creswell, J. W. (2003). Research design: Qualitative, quantitative, and mixed methods approaches. Thousand Oaks: CA, Sage Publications.

Creswell, J. W. (2007). Qualitative inquiry and research design. Choosing among the five approaches. Thousand Oaks, CA: Sage Publications.

Donaldson, T., \& Preston, L. E. (1995). The stakeholder theory of the corporation: Concepts, evidence and implications. The Academy of Management Review, 20, 65.

Eberle, D., Berens, G., \& Li, T. (2013). The impact of interactive corporate social responsibility communication on corporate reputation. Journal of Business Ethics, 118(4), 731-746.

Eisenhardt, K. M., \& Martin, J. A. (2000). Dynamic capabilities: What are they? Strategic Management Journal, 21, 1105-1121.

Fombrun, C. J. (2005). Building corporate reputation through CSR initiatives: Evolving standards. Corporate Reputation Review, 8(1), 7-11.

Freeman, R. E. (1984). Strategic management: A stakeholder approach. Boston: Pitman.

Freeman, R. E. (1999). Divergent stakeholder theory. The Academy of Management Review, 24, 233.

Gaskell, G. (2000). Individual and group interviewing. In M. Bauer \& G. Gaskell (Eds.), Qualitative researching with text, image and sound. London: Sage Publications.

Godfrey, P. C., Merrill, C. B., \& Hansen, J. M. (2009). The relationship between corporate social responsibility and shareholder value: An empirical test of the risk management hypothesis. Strategic Management Journal, 30(4), 425-445.

Greenley, G. E., Hooley, G. J., Broderick, A. J., \& Rudd, J. M. (2004). Strategic planning differences among different multiple stakeholder orientation profiles. Journal of Strategic Marketing, 12, 163.

Gubrium, J., \& Holstein, J. (2001). Handbook of constructionist research. London: Guildford Pres.

Helmig, B., Spraul, K., Ingenhoff, D. (2013). Under positive pressure: how stakeholder pressure affects corporate social responsibility implementation. Business \& Society. Published online before print March 4, 2013, doi:10.1177/0007650313477841 Business Society March 4, 20130007650313477841.

Hesse-Biber, S. N., \& Leavy, P. (2006). The practice of qualitative research. Thousand Oaks: CA, Sage Publications.

Hill, C. W. L., \& Jones, T. M. (1992). Stakeholder-agency theory. The Journal of Management Studies, 29, 131.

Hillman, A. J., \& Keim, G. D. (2001). Shareholder value, stakeholder management, and social issues: What's the bottom line? Strategic Management Journal, 22(2), 125-139.

ISO. (2013). ISO 26000 - Social responsibility. Retrieved October 13, 2013 from http://www.iso.org/iso/home/standards/iso26000.htm.

Kanter, R. (1999). From spare change to real change. Harvard Business Review, 77(3), 122-132.

Kraaijenbrink, J., Spender, J. C., \& Groen, A. J. (2010). The resourcebased view: A review and assessment of its critiques. Journal of Management, 36, 349-372.

Kuzel, A. J. (1999). Sampling in qualitative inquiry. In B. F. Crabtree \& W. L. Miller (Eds.), Doing qualitative research. Thousand Oaks, CA: Sage Publications.

Lai, C.-S., Chiu, C.-J., Yang, C.-F., \& Pai, D.-C. (2010). The effects of corporate social responsibility on brand performance: The mediating effect of industrial brand equity and corporate reputation. Journal of Business Ethics, 95(3), 457-469.

Lange, D., Lee, P. M., \& Dai, Y. (2011). Organizational reputation: A review. Journal of Management, 37(1), 153-184.

Lindgreen, A., Swaen, V., \& Johnston, W. (2009). Corporate social responsibility: An empirical investigation of U.S. organizations. Journal of Business Ethics, 85, 303-323. 
Maas, K., \& Liket, K. (2011). Talk the walk: Measuring the impact of strategic philanthropy. Journal of Business Ethics, 100(3), 445-464.

Maignan, I., Ferrell, O. C., \& Ferrell, L. (2005). A stakeholder model for implementing social responsibility in marketing. European Journal of Marketing, 39, 956.

Makadok, R. (2001). Toward a synthesis of the resource-based and dynamic-capability views of rent creation. Strategic Management Journal, 22(5), 387-401.

Maon, F., Lindgreen, A., \& Swaen, V. (2008). Thinking of the organization as a system: The role of managerial perceptions in developing a corporate social responsibility strategic agenda. Systems Research and Behavioral Science, 25(3), 413-426.

Maon, F., Lindgreen, A., \& Swaen, V. (2009). Designing and implementing corporate social responsibility: An integrative framework grounded in theory and practice. Journal of Business Ethics, 87(1), 71-89.

Maon, F., Lindgreen, A., \& Swaen, V. (2010). Organizational stages and cultural phases: A critical review and a consolidative model of corporate social responsibility development. International Journal of Management Reviews, 12, 20-38.

McAlister, D. T., \& Ferrell, L. (2002). The role of strategic philanthropy in marketing strategy. European Journal of Marketing, 36, 689.

McCracken, G. (1988). The long interview. Newbury Park, CA: Sage Publications.

McManus, J. (2002). The influence of stakeholder values on project management. Management Services, 46(8), 9.

McWilliams, A., \& Siegel, D. S. (2001). Corporate social responsibility: A theory of the firm perspective. Academy of Management. The Academy of Management Review, 26(1), 117-127.

McWilliams, A., Siegel, D. S., \& Wright, P. M. (2006). Corporate social responsibility: Strategic implications. Journal of Management Studies, 43, 1-18.

Middlemiss, N. (2003). Authentic not cosmetic: CSR as brand enhancement. Journal of Brand Management, 10(4/5), 353-361.

Miles, M. B. (1979). Qualitative data as an attractive nuisance: The problem of analysis. Administrative Science Quarterly, 24, 590-601.

Miles, M. B., \& Huberman, A. M. (1994). Qualitative data analysis: An expanded sourcebook. Thousand Oaks: Sage Publications.

Milne, M. J., \& Adler, R. W. (1999). Exploring the reliability of social and environmental disclosures content analysis. Accounting, Auditing \& Accountability Journal, 12, 237.

Mitchell, R. K., Agle, B. R., \& Wood, D. J. (1997). Toward a theory of stakeholder identification and salience: Defining the principle of who and what really counts. The Academy of Management Review, 22, 853.

Morimoto, R., Ash, J., \& Hope, C. (2005). Corporate social responsibility audit: From theory to practice. Journal of Business Ethics, 62(4), 315-325.

Munilla, L. S., \& Miles, M. P. (2005). The corporate social responsibility continuum as a component of stakeholder theory. Business and Society Review, 110, 371-387.

Murphy, B., Maguiness, P., Pescott, C., \& Wislang, S. (2005). Stakeholder perceptions presage holistic stakeholder relationship marketing performance. European Journal of Marketing, 39(9/ 10), 1049-1059.

Navarro, P. (1988). Why do corporations give to charity? The Journal of Business, 61(1), 65-93.

Neville, B., Bell, S. J., \& Whitwell, G. (2011). Stakeholder salience revisited: Refining, redefining, and refueling an underdeveloped conceptual tool. Journal of Business Ethics, 102(3), 357-378.

O’Riordan, L., \& Fairbrass, J. (2008). Corporate social responsibility (CSR): Models and theories in stakeholder dialogue. Journal of Business Ethics, 83(4), 745-758.
Oliver, R. W. (2000). Sustainable competitive advantage? The Journal of Business Strategy, 21(6), 7-9.

Patton, M. Q. (2002). Qualitative research and evaluation methods. London: Sage Publications Inc.

Peloza, J. L., \& Falkenberg, L. (2009). The role of collaboration in achieving corporate social responsibility objectives. California Management Review, 51(3), 95-113.

Peloza, J. L., \& Shang, J. (2011). How can corporate social responsibility activities create value for stakeholders? A systematic review. Journal of the Academy of Marketing Science, 39, 117-135.

Peters, T. J., \& Waterman, R. H, Jr. (1982). In search of excellence: Lessons from America's best-run companies. New York, Sydney: Harper \& Row.

Porter, M. E. (1991). Towards a dynamic theory of strategy. Strategic Management Journal, 12, 95-118.

Porter, M. E., \& Kramer, M. R. (2002). The competitive advantage of corporate philanthropy. Harvard Business Review, 80(12), 56-69.

Porter, M. E., \& Kramer, M. R. (2006). Strategy and society: The link between competitive advantage and corporate social responsibility. Harvard Business Review, 84(2), 78-93.

Ray, G., Barney, J. B., \& Muhanna, W. A. (2004). Capabilities, business processes, and competitive advantage: Choosing the dependent variable in empirical tests of the resource-based view. Strategic Management Journal, 25(1), 23-37.

Rothaermel, F. T. (2013). Strategic management: Concepts. New York, NY: McGraw-Hill/Irwin.

Russo, A., \& Perrini, F. (2010). Investigating stakeholder theory and social capital: CSR in large firms and SMEs. Journal of Business Ethics, 91(2), 207-221.

S\&P, Standard and Poor's Financial Services LLC. (2013). S\&P/ ASX200 [Online]. New York, NY. Retrieved March 20th 2014 from http://www.standardandpoors.com/indices/sp-asx-200/en/ us/?indexId=spausta200audff-p-au-

Saiia, D. H., Carroll, A. B., \& Buchholtz, A. K. (2003). Philanthropy as strategy: When corporate charity "Begins at Home". Business and Society, 42, 169-201.

Sargeant, A., \& Crissman, K. (2006). Corporate giving in Australia: An analysis of motives and barriers. Australian Journal of Social Issues, 41, 477-492.

Schnietz, K. E., \& Epstein, M. J. (2005). Exploring the financial value of a reputation for corporate social responsibility during a crisis. Corporate Reputation Review, 7(4), 327-345.

Sen, S., Bhattacharya, C. B., \& Korschun, D. (2006). The role of corporate social responsibility in strengthening multiple stakeholder relationships: A field experiment. Journal of the Academy of Marketing Science, 34(2), 158-166.

Sharfman, M. (1994). Changing institutional roles: The evolution of corporate philanthropy, 1883-1953. Business and Society, 33, 236.

Smith, N. (2009). Bounded goodness: Marketing implications of Drucker on corporate responsibility. Journal of the Academy of Marketing Science, 37, 73-84.

Smith, K. V., \& Bartunek, J. M. (2013). Embedded versus peripheral CSR from the perspective of CSR professionals. Industrial and Organizational Psychology, 6(4), 338-341.

Strauss, A., \& Corbin, J. (1998). Basics of qualitative research: Techniques and procedures for developing grounded theory. Thousand Oaks, CA: Sage Publications.

Teece, D. J., Pisano, G., \& Shuen, A. (1997). Dynamic capabilities and strategic management. Strategic Management Journal, 18(7), 509-533.

Thorne, D. M., Ferrell, O. C., \& Ferrell, L. (2011). Business and society: A strategic approach to social responsibility and ethics. Mason: Ohio South-Western Cengage Learning. 
Vanhamme, J., \& Grobben, B. (2009). Too good to be true! The effectiveness of CSR history in countering negative publicity. Journal of Business Ethics, 85(2), 273-283.

Vilanova, M., Lozano, J. M., \& Arenas, D. (2009). Exploring the nature of the relationship between CSR and competitiveness. Journal of Business Ethics, 87(1), 57-69.
Walters, D., \& Lancaster, G. (2000). Implementing value strategy through the value chain. Management Decision, 38(3), 160-178.

Wright, R. P., Paroutis, S. E., \& Blettner, D. P. (2013). How useful are the strategic tools we teach in business schools? Journal of Management Studies, 50(1), 92-125. 